\title{
Preferensi Metode Mengajar Dosen terhadap Sikap, Motivasi dan Minat Berwirausaha Mahasiswa Akuntansi Universitas Prima Indonesia
}

\author{
Tina Novianti Sitanggang ${ }^{1 *}$, Faathir Nurul Yasiin ${ }^{2}$ \\ Universitas Prima Indonesia ${ }^{1,2}$ \\ tinapaulus7371@gmail.com, faathirnurul91@gmail.com
}

*Corresponding Author

Submitted: November 24, 2020

Accepted: December 24, 2020

Published: February 1, 2021

\begin{abstract}
This study aims to analyze the effect of lecturer teaching methods on the Attitudes, Motivation and Entrepreneurial Interests of Accounting Students at Prima Indonesia University. This study uses primary data, namely by distributing questionnaires to 2015/2016 accounting students who have taken entrepreneurship courses with a sample of 236 students taken using the Slovin formula. This study was analyzed using SPSS. The result of the research is that simultaneously from the third variable independent of the dependent variable $Y$ (Entrepreneurial Interest) is $0.549 \times 100 \%=54.9 \%$. In other words, $54.9 \%$ of Entrepreneurial Interest can be expressed by the 3 independent variables (Entrepreneurial Knowledge, Attitudes and Motivation). Partially the 3 independent variables have a significant positive effect on Entrepreneurial Interest. Lecturer teaching method is proven as a variable that has a significant effect on the relationship between the independent variables and the dependent variable.
\end{abstract}

Keywords: Entrepreneurship; Attitudes; Motivation; Interests and Lecturer Teaching Methods

\section{PENDAHULUAN}

Pendidikan entpreneurship harus tahap "to be entrepreneur". Sehingga dalam pelaksanaan teknisnya para mahasiswa harus terjun langsung sehingga pendidikan kewirausahaan merupakan pendidikan yang 'dialami' langsung oleh pelaku. Di Universitas Prima Indonesia sendiri khususnya fakultas ekonomi telah mengadakan Festival Kewirausahaan yang di ikuti seluruh mahasiswa Universitas Prima Indonesiadan pelajar dari sejumlah SMA di Medan harapannya dengan diadakan Festival Kewirausahaan ini dapat meningkatkan minat mahasiswa untuk menjadi seorang wirausahaan. Yang menjadi permasalahannya saat ini adalah sejauh mana Metode mengajar Dosen mempengaruhi sikap, motivasi mahasiswa terhadap minat untuk berwirausahaan.

Tujuan belajar yang utama ialah bahwa yang dipelajari itu berguna di kemudian hari, yakni membantu kita untuk dapat belajar terus dengan cara yang lebih mudah, sehingga tercapai proses pembelajaran seumur hidup (long life education)Munandar (1987) . Menurut Suryana (2008) Pendekatan saintifik sendiri terdiri lima pengalaman belajar pokok yaitu 1) mengamati, 2) menanya, 3) mengumpulkan informasi, 4) mengasosiasi, dan 5) mengkomunikasikan. Pendekatan saintifik akan menjadi lebih bermakna, jika siswa dapat meningkatkan kemampuan mencipta sebuah produk. Kemampuan dalam mencipta suatu produk diperlukan adanya kreativitas. Pujiningsih (2010) dalam penelitian nya menjelskan bahwa mahasiswa akuntansi cenderung lebih menyukai dosen yang menjelaskan materi secara rinci atau bergaya dependen. Adel at al (2003) menjelaskan dalam penelitian nya sebagian mahasiswa akuntansi memiliki gaya converger, yakni gaya belajar dengan cara memikirkannya (Abstract Conceptualization/AC) serta memproses informasi yang diperoleh dengan cara memperaktikkannya ( Active experimentation/AE). Beberapa penelitian tersebut menghasilkan kesimpulan yang berbeda. 
Penelitian perlu dilakukan untuk mengetahui sejauh mana pengaruh metode mengajar dosen terhadap sikap, motivasi dan minat mahasiswa dalam berwirausaha, sehingga dosen-dosen mampu memperbaiki dan merancang metode mengajar yang lebih memotivasi apabila metode mengajar yang digunakan ternyata tidak memiliki pengaruh yang besar terhadap mahasiswa. Berdasarkan latar belakang tersebut, rumusan masalah adalah apakah metode mengajar dosen mempengaruhi sikap, motivasi dan minatberwirausaha mahasiswa program studi Akuntansi Universitas Prima Indonesia.

\section{STUDI LITERATUR}

Dosen adalah pendidik profesional dan ilmuwan dengan tugas utamanya adalah mentransformasikan, mengembangkan, dan menyebarluaskan ilmu pengetahuan, teknologi, dan seni melalui pendidikan, penelitian dan pengabdian masyarakat, UU No 14 (2005). Dalam kamus Besar Bahasa Indonesia dijelakan bahwa kompetensi adalah kewenangan atau kekuasaan untuk menentukan sesuatu hal, Fahmi (1995). Menurut Mulyasa (2019) Kompetensi merupakan perpaduan dari pengetahuan, keterampilan, nilai dan sikap yang direfleksikan dalam kebiasaan berfikir dan bertindak. Pada sistem pengajaran kompetnsi digunakan untuk menunjukkan pengetahuan dan konseptualisasi pada tingkat yang lebih tinggi.Dari pengertian diatas dapat kita simpulkan bahwa kompetensi merupakan seperangkat penguasaan kemampuan, keterampilan, nilai dan sikap yang haruslah di miliki oleh seorang Dosen sehingga seorang Dosen dapat menjalan tugas mengajarnya dengan metode yang menarik dan profesional sehingga dapat memicu minat, motivasi mahasiswa dalam berwirausahaan. Metode mengajar adalah cara yang dipergunakan oleh seorang dosen dalam mengadakan hubungan dengan mahasiswa pada saat berlangsungnya pengajaran. Menurut Saiful dan Aswan (2015), metode adalah strategi yang tidak bisa ditinggalkan dalam proses belajar mengajar. Menurut Sutikno (2009) menyatakan Metode Mengajar adalah cara-cara menyajikan materi pelajaran yang dilakukan oleh pendidik agar terjadi proses pembalajaran pada diri siswa dalam upaya untuk mencapai tujuan.

Penelitian yang telah dilakukan oleh Bambang (2014) dengan judul Pengembangan Jiwa Kewirausahaan di Kalangan Dosen menyatakan bahwa Dosen kewirausahaan menempati peran strategis dalam upaya pembekalan kewirausahaan pada mahasiswa. Dosen memerlukan penguatan dalam bentuk pendidikan, pelatihan, dan pemagangan yang membekali dirinya untuk lebih memahami ketrampilan berfikir dan bertindak ekonomis, berprinsip dan berperilaku ekonomis. Bambang mengatakan pada dasarnya pemerintah dan pimpinan Penrguruan Tinggi berperan penting dalam penumbuhan jiwa kewirausahaan, namun secara operasional terdapat 3 (tiga) unsur penting yang menjadi kunci keberhasilan pengembangan jiwa kewirausahaan di perguruan tinggi, yaitu mahasiswa, kurikulum, dan dosen pembina kewirausahaan.

\section{METODE}

Penelitian ini menggunakan pendekatan kuantitatif dengan menggunakan deskriptif analisis dan regresi linearberganda. Populasi yang digunakan dalam penelitian ini adalah seluruh mahasiswa jurusan akuntansi program S1 stambuk 2015/2016 di Universitas Prima Indonesia yang telah menyelesaikan mata kuliah pengantar kewirausahaan. Jumlah seluruh populasi 577 mahasiswa. Sedangkan sampel dalam penelitian ini adalah sebanyak 236 dipilih dengan menggunakan rumus Slovin.

Analisa data dilakukan dengan menggunakan metode analisa kuantitatif yaitu dengan mengumpulkan, mengolah, dan menginterpretasikan data yang diperoleh sehingga memberi keterangan yang benar dan lengkap untuk pemecahan masalah yang dihadapi. Metode analisis data yang digunakan dalam penelitian ini adalah model regresi berganda dengan menggunakan bantuanSPSS.

\section{Statistik Deskriptif}

\section{HASIL}

Hasil statistik deskriptif dapat menggambarkan deskripsi dari masing-masing variabel yang digunakan dalam penelitian ini yaitu pengetahuan kewirausahaan, sikap, motivasi, minat berwirausaha dan metode mengajar dosen. Statistik deskriptif menggambarkan variabel penelitian 
Owner: Riset \& Jurnal Akuntansi

e-ISSN : 2548-9224 |p-ISSN : 2548-7507

Volume 5 Nomor 1, Februari 2021

DOI : https://doi.org/10.33395/owner.v5i1.343

dengan mengungkapkan nilai minimum, nilai maksimum, nilai rata-rata (mean) dan nilai standar deviasi.

Tabel 1. Hasil Statistik Deskriptif

\begin{tabular}{|l|l|l|l|l|l|}
\hline \multicolumn{7}{|c|}{ Descriptive Statistics } \\
\hline & $\mathrm{N}$ & Minimum & Maximum & Mean & Std. Deviation \\
\hline Pengetahuan Kewirausahaan & 305 & 5.00 & 25.00 & 20.2361 & 3.10507 \\
\hline Sikap & 305 & 5.00 & 25.00 & 19.8918 & 3.03891 \\
\hline Motivasi & 305 & 5.00 & 25.00 & 19.4393 & 3.17636 \\
\hline Minat Berwirausaha & 305 & 5.00 & 25.00 & 19.8393 & 3.78498 \\
\hline Metode Mengajar Dosen & 305 & 15.00 & 25.00 & 20.4098 & 2.78256 \\
\hline Valid N (listwise) & 305 & & & & \\
\hline
\end{tabular}

Sumber : Data dioleh Peneliti

Tabel 2. Hasil Uji Koefisien Determinasi $\left(\mathrm{R}^{2}\right)$

\begin{tabular}{|l|l|l|l|l|}
\hline \multicolumn{3}{|c|}{ Model Summary $^{\mathbf{b}}$} \\
\hline Model & R & R Square & Adjusted R Square & Std. Error of the Estimate \\
\hline 1 & $.741^{\mathrm{a}}$ & .549 & .544 & 2.55464 \\
\hline
\end{tabular}

Sumber : Data dioleh Peneliti

Hasil koefisien determinasi menunjukkan seberapa kuat variabel independen yang digunakan mampu menggambarkan variabel dependen. Semakin besar nilai koefisien determinasi $\left(\mathrm{R}^{2}\right)$ menunjukkan bahwa kemampuan variabel independen juga semakin kuat (besar). Tabel di atas menunjukkan bahwa nilai $R$ Square $\left(\mathrm{R}^{2}\right)$ dalam penelitian ini adalah sebesar 0,549 yang berarti bawha pengetahuan kewirausahaan, sikap dan motivasi mampu menggambarkan atau menjelaskan minat berwirausaha sebesar 0,549 (54,9\%). Sedangkan sisanya yaitu sebesar 45,1\% digambarkan atau dijelaskan oleh variabel lain yang tidak digunakan dalam penelitian ini.

\section{Hasil Uji F (Simultan)}

Tabel 3. Hasil Uji F (Simultan)

\begin{tabular}{|c|c|c|c|c|c|c|}
\hline \multicolumn{7}{|c|}{ ANOVA $^{a}$} \\
\hline \multicolumn{2}{|c|}{ Model } & Sum of Squares & Df & Mean Square & $\mathrm{F}$ & Sig. \\
\hline \multirow[t]{3}{*}{1} & Regression & 2390.739 & 3 & 796.913 & 122.110 & $.000^{\mathrm{b}}$ \\
\hline & Residual & 1964.389 & 301 & 6.526 & & \\
\hline & Total & 4355.128 & 304 & & & \\
\hline
\end{tabular}

Sumber : Data dioleh Peneliti

Berdasarkan Tabel diatas dapat diketahui bahwa uji $\mathrm{F}$ menghasilkan $\mathrm{F}_{\text {hitung }}$ sebesar 122.110 dengan nilai signifikansi sebesar 0,000 $<0,05(\mathrm{a}=5 \%) \mathrm{F}$ tabel. Dari hasil ini dapat disimpulkan bahwa pengetahuan kewirausahaan, sikap dan motivasi secara simultan memiliki pengaruh yang signifikan terhadap minat berwirausaha. 
Owner: Riset \& Jurnal Akuntansi

e-ISSN : 2548-9224 |p-ISSN : 2548-7507

Volume 5 Nomor 1, Februari 2021

DOI : https://doi.org/10.33395/owner.v5i1.343

Uji Validitas Pengetahuan Kewirausahaan

Tabel 4. Hasil Uji Validitas Pengetahuan Kewirausahaan

\section{Correlations}

\begin{tabular}{|c|c|c|c|c|c|c|c|}
\hline & & $\mathrm{X} 1.1$ & $\mathrm{X} 1.2$ & $\mathrm{X} 1.3$ & X1.4 & $\mathrm{X} 1.5$ & $\begin{array}{l}\text { Pengetahuan } \\
\text { Kewirausahaan }\end{array}$ \\
\hline \multirow[t]{3}{*}{$\mathrm{X} 1.1$} & $\begin{array}{l}\text { Pearson } \\
\text { Correlation }\end{array}$ & 1 & $.592^{* *}$ & $.636^{* *}$ & $.640^{* * *}$ & $.433^{* *}$ & $.814^{* *}$ \\
\hline & Sig. (2-tailed) & & .000 & .000 & .000 & .000 & .000 \\
\hline & $\mathrm{N}$ & 305 & 305 & 305 & 305 & 305 & 305 \\
\hline \multirow[t]{3}{*}{$\mathrm{X} 1.2$} & $\begin{array}{l}\text { Pearson } \\
\text { Correlation }\end{array}$ & $.592^{* *}$ & 1 & $.696^{* *}$ & $.563^{* *}$ & $.510^{* * *}$ & $.816^{* *}$ \\
\hline & Sig. (2-tailed) & .000 & & .000 & .000 & .000 & .000 \\
\hline & $\mathrm{N}$ & 305 & 305 & 305 & 305 & 305 & 305 \\
\hline \multirow[t]{3}{*}{$\mathrm{X} 1.3$} & $\begin{array}{l}\text { Pearson } \\
\text { Correlation }\end{array}$ & $.636^{* *}$ & $.696^{* *}$ & 1 & $.651^{* *}$ & $.510^{* * *}$ & $.855^{* *}$ \\
\hline & Sig. (2-tailed) & .000 & .000 & & .000 & .000 & .000 \\
\hline & $\mathrm{N}$ & 305 & 305 & 305 & 305 & 305 & 305 \\
\hline \multirow[t]{3}{*}{$\mathrm{X} 1.4$} & $\begin{array}{l}\text { Pearson } \\
\text { Correlation }\end{array}$ & $.640^{* *}$ & $.563^{* *}$ & $.651^{* *}$ & 1 & $.510^{* *}$ & $.833^{* *}$ \\
\hline & Sig. (2-tailed) & .000 & .000 & .000 & & .000 & .000 \\
\hline & $\mathrm{N}$ & 305 & 305 & 305 & 305 & 305 & 305 \\
\hline \multirow[t]{3}{*}{$\mathrm{X} 1.5$} & $\begin{array}{l}\text { Pearson } \\
\text { Correlation }\end{array}$ & $.433^{* *}$ & $.510^{* * *}$ & $.510^{* *}$ & $.510^{* *}$ & 1 & $.740^{* *}$ \\
\hline & Sig. (2-tailed) & .000 & .000 & .000 & .000 & & .000 \\
\hline & $\mathrm{N}$ & 305 & 305 & 305 & 305 & 305 & 305 \\
\hline \multirow[t]{3}{*}{$\begin{array}{l}\text { Pengetahuan } \\
\text { Kewirausahaan }\end{array}$} & $\begin{array}{l}\text { Pearson } \\
\text { Correlation }\end{array}$ & $.814^{* * *}$ & $.816^{* * *}$ & $.855^{* *}$ & $.833^{* *}$ & $.740^{* * *}$ & 1 \\
\hline & Sig. (2-tailed) & .000 & .000 & .000 & .000 & .000 & \\
\hline & $\mathrm{N}$ & 305 & 305 & 305 & 305 & 305 & 305 \\
\hline
\end{tabular}

**. Correlation is significant at the 0.01 level (2-tailed).

Sumber : Data dioleh Peneliti

Sebelum melakukan interpretasi pada uji validitas, maka terlebih dahulu harus diketahui nilai $r$ tabel untuk penelitian ini. Nilai $r$ tabel didapatkan dengan melihat tabel $r$ dengan total $N=$ 305 , nilai $\mathrm{df}=305-2=303$, dan signifikansi $5 \%$. Dengan ketentuan tersebut, maka nilai $\mathrm{r}$ tabel yang digunakan dalam penelitian ini adalah sebesar $=0,112$.

Sebuah konstruk dikatakan valid jika memiliki nilai $r$ hitung yang lebih besar dari $r$ tabelnya. Sehingga hasil pengujian di atas menunjukkan bahwa masing-masing konstruk (pertanyaan) yang digunakan dalam kuesioner pengetahuan kewirausahaan dinyatakan valid karena nilai r yang didapatkan lebih besar dari 0,112 .

Uji Reliabilitas Pengetahuan Kewirausahaan

Tabel 5. Hasil Uji Reliabilitas Pengetahuan Kewirausahaan

\section{Case Processing Summary}

\begin{tabular}{lllll} 
& & $\mathrm{N}$ & $\%$ \\
\hline Cases & Valid $^{\mathrm{a}}$ & 305 & 100.0 \\
\cline { 2 - 4 } & Excluded $^{\mathrm{a}}$ & 0 & .0 \\
\cline { 2 - 4 } & Total & 305 & 100.0 \\
\hline
\end{tabular}

a. Listwise deletion based on all variables in the procedure. 
Owner: Riset \& Jurnal Akuntansi

e-ISSN : 2548-9224 |p-ISSN : 2548-7507

Volume 5 Nomor 1, Februari 2021

DOI : https://doi.org/10.33395/owner.v5i1.343

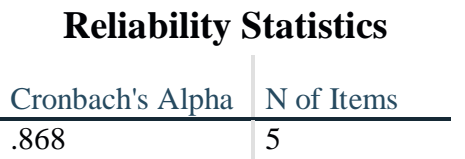

Sumber : Data dioleh Peneliti

Kuesioner dinyatakan memiliki tingkat reliabilitas yang baik jika nilai Cronbach's Alpha yang dihasilkan melebihi 0,6 . Sehingga berdasarkan tabel di atas maka dapat diketahui bahwa kuesioner dalam variabel pengetahuan kewirausahaan dapat dinyatakan reliabel karena memiliki nilai Cronbach's Alpha sebesar 0,868 yang lebih besar dari 0,6.

\section{Uji Validitas Sikap}

Tabel 6. Hasil Uji Validitas Sikap

\begin{tabular}{|c|c|c|c|c|c|c|c|}
\hline \multicolumn{8}{|c|}{ Correlations } \\
\hline & & $\mathrm{X} 2.1$ & $\mathrm{X} 2.2$ & $\mathrm{X} 2.3$ & $\mathrm{X} 2.4$ & $\mathrm{X} 2.5$ & Sikap \\
\hline \multirow[t]{3}{*}{$\mathrm{X} 2.1$} & Pearson Correlation & 1 & $.647^{* *}$ & $.360^{* *}$ & $.505^{* *}$ & $.413^{* *}$ & $.742^{* *}$ \\
\hline & Sig. (2-tailed) & & .000 & .000 & .000 & .000 & .000 \\
\hline & $\mathrm{N}$ & 305 & 305 & 305 & 305 & 305 & 305 \\
\hline \multirow[t]{3}{*}{$\mathrm{X} 2.2$} & Pearson Correlation & $.647^{* *}$ & 1 & $.524^{* *}$ & $.674^{* *}$ & $.522^{* *}$ & $.847^{* *}$ \\
\hline & Sig. (2-tailed) & .000 & & .000 & .000 & .000 & .000 \\
\hline & $\mathrm{N}$ & 305 & 305 & 305 & 305 & 305 & 305 \\
\hline \multirow[t]{3}{*}{$\mathrm{X} 2.3$} & Pearson Correlation & $.360^{* *}$ & $.524^{* *}$ & 1 & $.530^{* *}$ & $.567^{* *}$ & $.749^{* *}$ \\
\hline & Sig. (2-tailed) & .000 & .000 & & .000 & .000 & .000 \\
\hline & $\mathrm{N}$ & 305 & 305 & 305 & 305 & 305 & 305 \\
\hline \multirow[t]{3}{*}{$\mathrm{X} 2.4$} & Pearson Correlation & $.505^{* *}$ & $.674^{* *}$ & $.530^{* *}$ & 1 & $.597^{* *}$ & $.834^{* * *}$ \\
\hline & Sig. (2-tailed) & .000 & .000 & .000 & & .000 & .000 \\
\hline & $\mathrm{N}$ & 305 & 305 & 305 & 305 & 305 & 305 \\
\hline \multirow[t]{3}{*}{$\mathrm{X} 2.5$} & Pearson Correlation & $.413^{* *}$ & $.522^{* *}$ & $.567^{* *}$ & $.597^{* *}$ & 1 & $.787^{* *}$ \\
\hline & Sig. (2-tailed) & .000 & .000 & .000 & .000 & & .000 \\
\hline & $\mathrm{N}$ & 305 & 305 & 305 & 305 & 305 & 305 \\
\hline \multirow[t]{3}{*}{ Sikap } & Pearson Correlation & $.742^{* *}$ & $.847^{* *}$ & $.749^{* *}$ & $.834^{* *}$ & $.787^{* *}$ & 1 \\
\hline & Sig. (2-tailed) & .000 & .000 & .000 & .000 & .000 & \\
\hline & $\mathrm{N}$ & 305 & 305 & 305 & 305 & 305 & 305 \\
\hline
\end{tabular}

Sumber : Data dioleh Peneliti

Sebuah konstruk dikatakan valid jika memiliki nilai $r$ hitung yang lebih besar dari $r$ tabelnya. Sehingga hasil pengujian di atas menunjukkan bahwa masing-masing konstruk (pertanyaan) yang digunakan dalam kuesioner sikap dapat dinyatakan valid karena masing-masing nilai $r$ yang didapatkan lebih besar dari 0,112 .

Uji Reliabilitas Sikap

Tabel 7. Hasil Uji Reliabilitas Sikap

Case Processing Summary

\begin{tabular}{ll|l|l} 
& & $\mathrm{N}$ & $\%$ \\
\hline \multirow{3}{*}{ Cases } & Valid $^{2}$ & 305 & 100.0 \\
\cline { 2 - 4 } & Excluded $^{\mathrm{a}}$ & 0 & .0 \\
\cline { 2 - 4 } & Total & 305 & 100.0 \\
\hline \multirow{2}{*}{ T. } & &
\end{tabular}

a. Listwise deletion based on all variables in the procedure. 
Owner: Riset \& Jurnal Akuntansi

e-ISSN : 2548-9224 |p-ISSN : 2548-7507

Volume 5 Nomor 1, Februari 2021

DOI : https://doi.org/10.33395/owner.v5i1.343

Reliability Statistics

\begin{tabular}{l|l} 
Cronbach's Alpha & N of Items \\
\hline
\end{tabular}

\begin{tabular}{l|l}
$.850 \quad$ Sumber : \\
\hline
\end{tabular}

Sumber : Data dioleh Peneliti

Kuesioner dinyatakan memiliki tingkat reliabilitas yang baik jika nilai Cronbach's Alpha yang dihasilkan melebihi 0,6. Sehingga berdasarkan tabel di atas maka dapat diketahui bahwa kuesioner dalam variabel sikap dapat dinyatakan reliabel karena memiliki nilai Cronbach's Alpha sebesar 0,850 yang lebih besar dari 0,6 .

\section{Uji Validitas Motivasi}

Tabel 8. Hasil Uji Validitas Motivasi

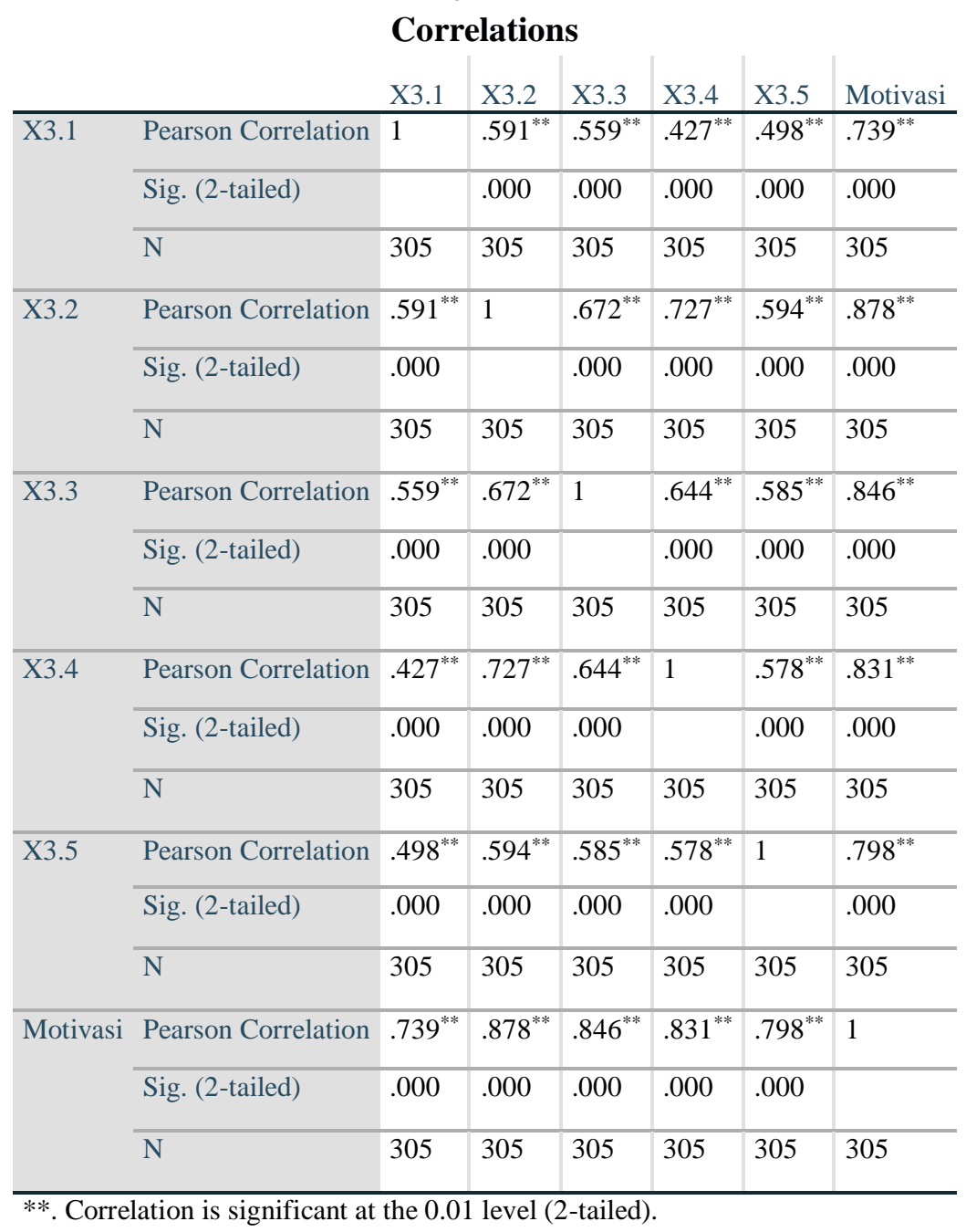

Sumber : Data dioleh Peneliti

Sebuah konstruk dikatakan valid jika memiliki nilai $r$ hitung yang lebih besar dari $\mathrm{r}$ tabelnya. Sehingga hasil pengujian di atas menunjukkan bahwa masing-masing konstruk (pertanyaan) yang digunakan dalam kuesioner motivasi dapat dinyatakan valid karena masingmasing nilai $r$ yang didapatkan lebih besar dari 0,112 . 
Owner: Riset \& Jurnal Akuntansi

e-ISSN : 2548-9224 |p-ISSN : 2548-7507

Volume 5 Nomor 1, Februari 2021

DOI : https://doi.org/10.33395/owner.v5i1.343

\section{Uji Reliabilitas Motivasi}

Tabel 9. Hasil Uji Reliabilitas Motivasi

Case Processing Summary

\begin{tabular}{|c|c|c|c|}
\hline & & $\mathrm{N}$ & $\%$ \\
\hline \multirow[t]{3}{*}{ Cases } & Valid & 305 & 100.0 \\
\hline & Excluded $^{\mathrm{a}}$ & 0 & .0 \\
\hline & Total & 305 & 100.0 \\
\hline
\end{tabular}

a. Listwise deletion based on all variables in the procedure.

\section{Reliability Statistics}

\begin{tabular}{l|l} 
Cronbach's Alpha & N of Items
\end{tabular}

$\frac{5}{.877 \quad \text { Sumber : Data dioleh Peneliti }}$

Kuesioner dinyatakan memiliki tingkat reliabilitas yang baik jika nilai Cronbach's Alpha yang dihasilkan melebihi 0,6. Sehingga berdasarkan tabel di atas maka dapat diketahui bahwa kuesioner dalam variabel motivasi dapat dinyatakan reliabel karena memiliki nilai Cronbach's Alpha sebesar 0,877 yang lebih besar dari 0,6.

\section{Uji Validitas Minat Berwirausaha}

Tabel 10. Hasil Uji Validitas Minat Berwirausaha

\section{Correlations}

\begin{tabular}{|c|c|c|c|c|c|c|c|}
\hline & & Y.1 & Y.2 & Y.3 & Y.4 & Y.5 & Minat Berwirausaha \\
\hline \multirow[t]{3}{*}{ Y.1 } & Pearson Correlation & 1 & $.809^{* *}$ & $.525^{* * *}$ & $.658^{* *}$ & $.463^{* *}$ & $.808^{* *}$ \\
\hline & Sig. (2-tailed) & & .000 & .000 & .000 & .000 & .000 \\
\hline & $\mathrm{N}$ & 305 & 305 & 305 & 305 & 305 & 305 \\
\hline \multirow[t]{3}{*}{ Y.2 } & Pearson Correlation & $.809^{* *}$ & 1 & $.585^{* *}$ & $.709^{* *}$ & $.518^{* *}$ & $.846^{* *}$ \\
\hline & Sig. (2-tailed) & .000 & & .000 & .000 & .000 & .000 \\
\hline & $\mathrm{N}$ & 305 & 305 & 305 & 305 & 305 & 305 \\
\hline \multirow[t]{3}{*}{ Y.3 } & Pearson Correlation & $.525^{* *}$ & $.585^{* *}$ & 1 & $.724^{* *}$ & $.864^{* *}$ & $.874^{* *}$ \\
\hline & Sig. (2-tailed) & .000 & .000 & & .000 & .000 & .000 \\
\hline & $\mathrm{N}$ & 305 & 305 & 305 & 305 & 305 & 305 \\
\hline \multirow[t]{3}{*}{ Y.4 } & Pearson Correlation & $.658^{* *}$ & $.709^{* *}$ & $.724^{* *}$ & 1 & $.706^{* *}$ & $.889^{* *}$ \\
\hline & Sig. (2-tailed) & .000 & .000 & .000 & & .000 & .000 \\
\hline & $\mathrm{N}$ & 305 & 305 & 305 & 305 & 305 & 305 \\
\hline \multirow[t]{3}{*}{ Y.5 } & Pearson Correlation & $.463^{* *}$ & $.518^{* * *}$ & $.864^{* * *}$ & $.706^{* * *}$ & 1 & $.840^{* * *}$ \\
\hline & Sig. (2-tailed) & .000 & .000 & .000 & .000 & & .000 \\
\hline & $\mathrm{N}$ & 305 & 305 & 305 & 305 & 305 & 305 \\
\hline \multirow[t]{3}{*}{ Minat Berwirausaha } & Pearson Correlation & $.808^{* *}$ & $.846^{* *}$ & $.874^{* *}$ & $.889^{* *}$ & $.840^{* *}$ & 1 \\
\hline & Sig. (2-tailed) & .000 & .000 & .000 & .000 & .000 & \\
\hline & $\mathrm{N}$ & 305 & 305 & 305 & 305 & 305 & 305 \\
\hline
\end{tabular}

**. Correlation is significant at the 0.01 level (2-tailed).

\section{Sumber : Data dioleh Peneliti}

Sebuah konstruk dikatakan valid jika memiliki nilai $r$ hitung yang lebih besar dari $r$ tabelnya. Sehingga hasil pengujian di atas menunjukkan bahwa masing-masing konstruk (pertanyaan) yang digunakan dalam kuesioner minat berwirausaha dapat dinyatakan valid karena masing-masing nilai r yang didapatkan lebih besar dari 0,112 . 
Owner: Riset \& Jurnal Akuntansi

e-ISSN : 2548-9224 |p-ISSN : 2548-7507

Volume 5 Nomor 1, Februari 2021

DOI : https://doi.org/10.33395/owner.v5i1.343

\section{Uji Reliabilitas Minat Berwirausaha}

Tabel 11. Hasil Uji Reliabilitas Minat Berwirausaha

Case Processing Summary

\begin{tabular}{lll|l} 
& & $\mathrm{N}$ & $\%$ \\
\hline Cases & Valid $^{\mathrm{a}}$ & 305 & 100.0 \\
\cline { 2 - 4 } & Excluded $^{\mathrm{a}}$ & 0 & .0 \\
\cline { 2 - 4 } & Total & 305 & 100.0 \\
\hline
\end{tabular}

a. Listwise deletion based on all variables in the procedure.

\section{Reliability Statistics \\ \begin{tabular}{l|l} 
Cronbach's Alpha & $\mathrm{N}$ of Items \\
\hline .904 & 5
\end{tabular}}

Sumber : Data dioleh Peneliti

Kuesioner dinyatakan memiliki tingkat reliabilitas yang baik jika nilai Cronbach's Alpha yang dihasilkan melebihi 0,6. Sehingga berdasarkan tabel di atas maka dapat diketahui bahwa kuesioner dalam variabel minat berwirausaha dapat dinyatakan reliabel karena memiliki nilai Cronbach's Alpha sebesar 0,904 yang lebih besar dari 0,6.

\section{Uji Validitas Metode Mengajar Dosen}

Tabel 12. Hasil Uji Validitas Metode Mengajar Dosen

\section{Correlations}

\begin{tabular}{|c|c|c|c|c|c|c|c|}
\hline & & Z.1 & Z.2 & Z.3 & $\mathrm{Z} .4$ & Z.5 & Metode Mengajar Dosen \\
\hline \multirow[t]{3}{*}{$\bar{Z} .1$} & Pearson Correlation & 1 & $.896^{* *}$ & $.868^{* * *}$ & $.774^{* *}$ & $.896^{* *}$ & $.976^{* *}$ \\
\hline & Sig. (2-tailed) & & .000 & .000 & .000 & .000 & .000 \\
\hline & $\mathrm{N}$ & 305 & 305 & 305 & 305 & 305 & 305 \\
\hline \multirow[t]{3}{*}{$\mathrm{Z} .2$} & Pearson Correlation & $.896^{* *}$ & 1 & $.692^{* *}$ & $.752^{* *}$ & $.880^{* *}$ & $.925^{* *}$ \\
\hline & Sig. (2-tailed) & .000 & & .000 & .000 & .000 & .000 \\
\hline & $\mathrm{N}$ & 305 & 305 & 305 & 305 & 305 & 305 \\
\hline \multirow[t]{3}{*}{ Z.3 } & Pearson Correlation & $.868^{* *}$ & $.692^{* *}$ & 1 & $.513^{* *}$ & $.692^{* *}$ & $.834^{* *}$ \\
\hline & Sig. (2-tailed) & .000 & .000 & & .000 & .000 & .000 \\
\hline & $\mathrm{N}$ & 305 & 305 & 305 & 305 & 305 & 305 \\
\hline \multirow[t]{3}{*}{ Z.4 } & Pearson Correlation & $.774^{* *}$ & $.752^{* *}$ & $.513^{* *}$ & 1 & $.856^{* *}$ & $.858^{* *}$ \\
\hline & Sig. (2-tailed) & .000 & .000 & .000 & & .000 & .000 \\
\hline & $\mathrm{N}$ & 305 & 305 & 305 & 305 & 305 & 305 \\
\hline \multirow[t]{3}{*}{ Z.5 } & Pearson Correlation & $.896^{* *}$ & $.880^{* *}$ & $.692^{* * *}$ & $.856^{* *}$ & 1 & $.949^{* *}$ \\
\hline & Sig. (2-tailed) & .000 & .000 & .000 & .000 & & .000 \\
\hline & $\mathrm{N}$ & 305 & 305 & 305 & 305 & 305 & 305 \\
\hline \multirow[t]{3}{*}{ Metode Mengajar Dosen } & Pearson Correlation & $.976^{* *}$ & $.925^{* *}$ & $.834^{* *}$ & $.858^{* *}$ & $.949^{* * *}$ & 1 \\
\hline & Sig. (2-tailed) & .000 & .000 & .000 & .000 & .000 & \\
\hline & $\mathrm{N}$ & 305 & 305 & 305 & 305 & 305 & 305 \\
\hline
\end{tabular}

**. Correlation is significant at the 0.01 level (2-tailed).

Sumber : Data dioleh Peneliti 
Sebuah konstruk dikatakan valid jika memiliki nilai $r$ hitung yang lebih besar dari $r$ tabelnya. Sehingga hasil pengujian di atas menunjukkan bahwa masing-masing konstruk (pertanyaan) yang digunakan dalam kuesioner metode mengajar dosen dapat dinyatakan valid karena masing-masing nilai $r$ yang didapatkan lebih besar dari 0,112 .

\section{Uji Reliabilitas Metode Mengajar Dosen}

Tabel 13. Hasil Uji Reliabilitas Metode Mengajar Dosen

\section{Case Processing Summary}

\begin{tabular}{|c|c|c|c|}
\hline & & $\mathrm{N}$ & $\%$ \\
\hline \multirow[t]{3}{*}{ Cases } & Valid & 305 & 100.0 \\
\hline & Excluded $^{\mathrm{a}}$ & 0 & .0 \\
\hline & Total & 305 & 100.0 \\
\hline
\end{tabular}

\section{Reliability Statistics

\begin{tabular}{l|l} 
Cronbach's Alpha & N of Items \\
\hline .943 & 5
\end{tabular}

Sumber : Data dioleh Peneliti

Kuesioner dinyatakan memiliki tingkat reliabilitas yang baik jika nilai Cronbach's Alpha yang dihasilkan melebihi 0,6 . Sehingga berdasarkan tabel di atas maka dapat diketahui bahwa kuesioner dalam variabel metode mengajar dosendapat dinyatakan reliabel karena memiliki nilai Cronbach's Alpha sebesar 0,943 yang lebih besar dari 0,6.

\section{Multikolinearitas}

Suatu model penelitian terbebas dari gejala multikolinearitas jika memiliki nilai tolerance yang lebih besar dari 0,1 serta memiliki nilai VIF yang lebih kecil dari 10. Tabel di atas menunjukkan bahwa tidak terjadi masalah multikolinearitas karena masing-masing dari variabel independen yang digunakan dalam penelitian ini memiliki nilai tolerance yang lebih besar dari 0,1 dan memiliki nilai VIF yang lebih kecil dari 10.

\section{Uji t (Parsial)}

Suatu variabel independen dikatakan mampu mempengaruhi variabel dependen secara parsial jika nilai signifikansi yang dihasilkan lebih kecil dari 0,05 . Sedangkan jika nilai signifikansi yang dihasilkan lebih besar dari 0,05 maka variabel tersebut diyatakan tidak memiliki pengaruh yang signifikan terhadap variabel dependen

Tabel 14. Uji t (Parsial)

\begin{tabular}{|c|c|c|c|c|c|c|c|}
\hline \multicolumn{8}{|l|}{ Coefficients $^{\mathrm{a}}$} \\
\hline \multirow[b]{2}{*}{ Model } & \multicolumn{2}{|c|}{$\begin{array}{l}\text { Unstandardized } \\
\text { Coefficients }\end{array}$} & \multirow{2}{*}{\begin{tabular}{|l|}
$\begin{array}{l}\text { Standardized } \\
\text { Coefficients }\end{array}$ \\
Beta \\
\end{tabular}} & \multirow[b]{2}{*}{$\mathrm{T}$} & \multirow[b]{2}{*}{ Sig. } & \multicolumn{2}{|c|}{$\begin{array}{l}\text { Collinearity } \\
\text { Statistics }\end{array}$} \\
\hline & $\mathrm{B}$ & Std. Error & & & & Tolerance & VIF \\
\hline \begin{tabular}{l|l}
1 & (Constant) \\
\end{tabular} & -.028 & 1.057 & & -.026 & .979 & & \\
\hline \begin{tabular}{|l|} 
Pengetahuan \\
Kewirausahaan
\end{tabular} & .334 & .074 & .274 & 4.490 & .000 & .402 & 2.488 \\
\hline Sikap & .373 & .076 & .299 & 4.913 & .000 & .404 & 2.474 \\
\hline Motivasi & .293 & .081 & .246 & 3.611 & .000 & .324 & 3.091 \\
\hline
\end{tabular}

a. Dependent Variable: Minat Berwirausaha

Sumber : Data dioleh Peneliti 
Dari hasil perhitungan diatas diketahui bahwa nilai t-hitung pengetahuan kewirausahaan sebesar $\mathrm{t}$-hitung $4,490>\mathrm{t}$-tabel pada tingkat signifikansi sebesar $0.000<0,05$ hal ini berarti Pengetahuan Kewirausahaan berpengaruh terhadap minat berwirausaha. Demikian hal nya dengan hasil perhitungan variabel sikap yaitu nilai $t_{\text {-hitung }}$ Sikap sebesar $t_{\text {-hitung }} 4,913>\mathrm{t}_{\text {-tabel }}$ pada tingkat signifikansi sebesar $0.000<0,05$ hal ini berarti variabel sikap berpengaruh terhadap minat berwirausaha. Untuk variabel motivasi juga berpengaruh terhadap minat berwirausaha dengan nilai $\mathrm{t}$-hitung motivasi sebesar $\mathrm{t}$-hitung 3,611 $>\mathrm{t}$-tabel pada tingkat signifikansi sebesar $0.000<0,05$ hal ini berarti motivasi berpengaruh terhadap minat berwirausaha.

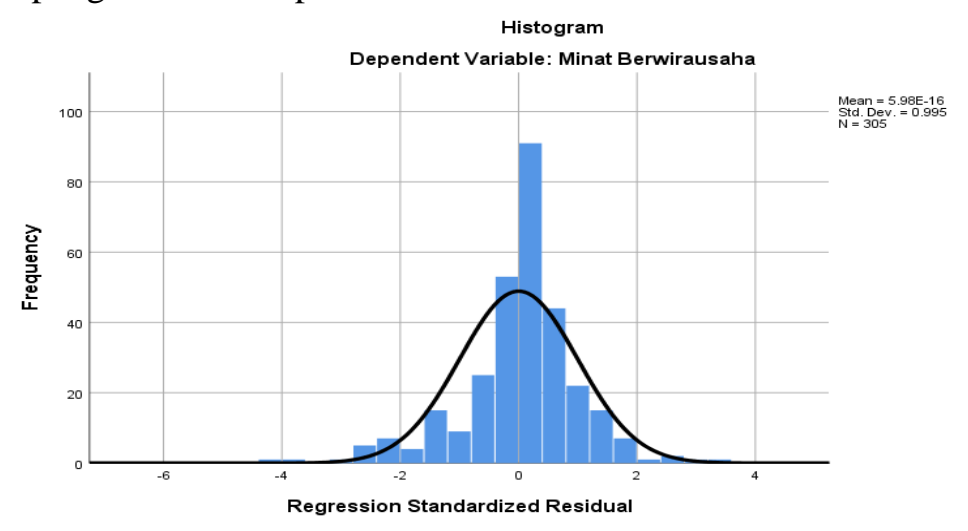

Gambar 1. Hasil Uji Normalitas

Sumber : Data dioleh Peneliti

Uji normalitas seperti yang ditampilkan oleh grafik diatas merupakan hasil pengujian normalitas dengan pendekatan histogram. Berdasarkan gambar di atas, maka terlihat kurva yang berbentuk kurva normal, sehingga dapat disimpulkan bahwa data yang digunakan dalam penelitian ini telah berdistribusi secara normal.

Tabel 15. Hasil Pengujian Variabel Moderating

\begin{tabular}{|c|c|c|c|c|c|c|}
\hline \multicolumn{7}{|c|}{ Coefficients $^{\mathbf{a}}$} \\
\hline \multirow{2}{*}{\multicolumn{2}{|c|}{ Model }} & \multicolumn{2}{|c|}{$\begin{array}{l}\text { Unstandardized } \\
\text { Coefficients }\end{array}$} & \multirow{3}{*}{$\begin{array}{l}\text { Standardized } \\
\text { Coefficients } \\
\text { Beta } \\
\end{array}$} & \multirow{3}{*}{$\begin{array}{l}\mathrm{T} \\
-.824\end{array}$} & \multirow{3}{*}{$\begin{array}{l}\text { Sig. } \\
.410\end{array}$} \\
\hline & & \multirow{2}{*}{$\begin{array}{l}\mathrm{B} \\
-5.985\end{array}$} & \multirow{2}{*}{\begin{tabular}{|l|} 
Std. Error \\
7.260 \\
\end{tabular}} & & & \\
\hline 1 & (Constant) & & & & & \\
\hline & $\begin{array}{l}\text { Pengetahuan } \\
\text { Kewirausahaan }\end{array}$ & .530 & .493 & .435 & 1.075 & .283 \\
\hline & Sikap & 1.693 & .558 & 1.359 & 3.035 & .003 \\
\hline & Motivasi & -.966 & .610 & -.810 & -1.582 & .115 \\
\hline & $\begin{array}{l}\text { Metode Mengajar } \\
\text { Dosen }\end{array}$ & .298 & .353 & .219 & .845 & .399 \\
\hline & $\mathrm{X} 1 \_\mathrm{Z}$ & -.010 & .024 & -.223 & -.397 & .691 \\
\hline & X2_Z & -.064 & .027 & -1.506 & -2.387 & .018 \\
\hline & X3_Z & .061 & .029 & 1.423 & 2.072 & .039 \\
\hline
\end{tabular}

Sumber : Data dioleh Peneliti

Variabel moderating yang digunakan dalam penelitian ini adalah metode mengajar dosen. Untuk melihat mampukah metode mengajar dosen dijadikan sebagai variabel moderating dalam model penelitian ini maka dapat dilihat berdasarkan interaksinya terhadap model penelitian. 
Berdasarkan tabel di atas, dapat dilihat masing interaksi antara variabel moderating yaitu metode mengajar dosen dengan masing-masing variabel independen dalam penelitian ini yaitu pengetahuan kewirausahaan, sikap dan motivasi. Berdasarkan hasil tersebut dapat diketahui bahwa interaksi yang memiliki pengaruh yang signifikan terhadap minat berwirausaha adalah interaksi $\mathrm{X}_{2} \mathrm{Z}$ dan $\mathrm{X}_{3} \_\mathrm{Z}$. Sedangkan interaksi $\mathrm{X}_{1 \_} \mathrm{Z}$ tidak signifikan pada taraf $5 \%$.

\section{PEMBAHASAN}

Metode pengajaran dengan memberikan tugas dan ceramah adalah metode pengajaran tradisonal, dan untuk mata kuliah kewirausahaan metode tradisonal ini tidak lah tepat diterapkan mengingat mata kuliah kewirausahaan merupakan mata kuliah yang membutuhkan praktek langsung, membiarkan mahasiswa terjun di dalam berwirausaha. Metode pengajaran dengan Kuliah dalam bentuk seminar atau workshop adalah metode yang sangat tepat untuk diterapkan di mata kuliah kewirausahaan, karena dengan adanya workshop Kewirausahaan perguruan tinggi dapat langsung melibatkan mahasiswa dan merupakan wadah yang menfasilitasi mhasiswa dalam berwirausaha, dengan demikian dapat mempengaruhi sikap, motivasi dan minat berwirausaha mahasiswa. Dosen merupakan fasilitator di dalam pembelajaran, untuk itu seorang dosen harus lah mampu menguasai ilmu yang diajarkan kepada mahasiswa, mampu mengelola dan mengendalikan proses belajar mengajar dengan metode mengajar yang baik. sebagai fasilitator. Beberapa keterampilan mengajar yang harus dikuasai oleh dosen yaitu (1) keterampilan bertanya dasar, (2) keterampilan bertanya lanjut, (3) keterampilan memberi penguatan, (4) keterampilan mengadakan variasi, (5) keterampilan menjelaskan, (6) keterampilan membuka dan menutup pelajaran, (7) keterampilan mengelola kelas, (8) keterampilan memimpin diskusi kelompok kecil, (9) keterampilan mengajar kelompok kecil dan perorangan. Dengan demikian dosen yang telah menguasai keterampilan mengajar akan menciptakan kondisi belajar mengajar yang efektif dan interaksi antara dosen dengan mahasiswa sehingga dapat merangsang sikap, motivasi dan minat berwirausaha mahasiswa. Penelitian ini sejalan dengan penelitian Pujiningsih (2010) dan Penelitian yang telah dilakukan oleh Bambang (2014) yang menyatakan bahwa metode mengajar dosen sangat mempengaruhi Sikap, Motivasi dan Minat mahasiswa dalam Berwirausaha. Penelitian ini tidak sejalan dengan Adel at al (2003).

\section{KESIMPULAN}

Secara parsial Pengetahuan Kewirausahaan, Sikap, dan Motivasi berpengaruh positif signifikan terhadap Minat Berwirausaha. Hasil uji moderating tersebut di atas memperlihatkan bahwa k-3 variabel bebas yaitu Sikap dan Motivasi berpengaruh positif signifikan terhadap Minat Berwirausaha, sedangkan Pengetahuan Kewirausahaan berpengaruh positif tetapi tidak signifikan terhadap Minat Berwirausaha dengan nilai sig > $5 \%$. Metode Mengajar Dosen sebagai variabel moderating berpengaruh signifikan terhadap hubungan antara variabel bebas terhadap variabel terikat. Dengan kata lain, Metode Mengajar Dosen terbukti sebagai variabel pemoderasi yang menghubungan variabel bebas dengan variabel terikat.

\section{UCAPAN TERIMA KASIH}

Peneliti mengucapkan terimakasih kepada Kementerian Riset dan Teknologi/Badan Riset dan Inovasi Nasional (RISTEK-BRIN) atas hibah penelitian dosen pemula dengan nomor kontrak : 282/LL1/PG/2020 sehingga penelitian ini dapat terselesaikan dengan baik. Peneliti juga mengucapkan terimakasih kepada Rektor Universitas Prima Indonesia atas dukungan dan fasilitas selama proses penyelesaian penelitian ini..

\section{REFERENSI}

Adel at al. 2003. An Investigation into preferred Learning Styles of Accounting, Management, Marketing, and General Business Majors, Teaching \& Learning, 18(1):24-31

Bahri D Syaiful dan Aswan Zain (2015). Strategi Belajar Mengajar. Jakarta: Rineka Cipta. Dimyati dan Mudjiono. 2006. Belajar dan Pembelajaran. Jakarta; PT. Rajagrafindo Perkasa. Dr.M. Sorby Sutikno, (2009). Belajar dan Pembelajaran, Prospect. Bandung. Fahmi Idrus, Kamus Bahasa Indonesia,(Jakarta: Greisinda Press,1995), h. 383 
Owner: Riset \& Jurnal Akuntansi

e-ISSN : 2548-9224 |p-ISSN : 2548-7507

Volume 5 Nomor 1, Februari 2021

DOI : https://doi.org/10.33395/owner.v5i1.343

Mulyasa, StandarKompetensi dan Sertifikasi Guru. Bandung: PT RemajaRosdakarya, 2009.

Munandar, Utami. 1987. Mengembangkan Bakat dan Kreativitas Anak Sekolah. Jakarta: Gramedia

Siswoyo, Bambang Banu 2009 , "Pengembangan Jiwa Kewirausahaan di Kalangan Dosen dan Mahasiswa", Jurnal Ekonomi Bisnis No. 2 Tahun 2014.

Suryana, M.Si. (2008). Kewirausahaan Pedoman praktis: Kiat dan Proses Menuju Sukses. Jakarta: Salemba Empat

Undang -Undang RI No. 14 tahun 2005 tentang Guru dan Dosen (https://man1bengkalis.sch.id/blog/undang-undang-no-14-tahun-2005-tentang-guru-dandosen)

Pujiningsih, S. 2010. Preferensi Gaya Belajar Mahasiswa Akuntansi. Jurnal Akuntansi EI Muhasaba, 1 (2):10-112 